\title{
LORD LUGARD: A PRELIMINARY EVALUATION
}

\section{MARGERY PERHAM}

$\Gamma^{\mathrm{O}}$ give the first Lugard Memorial Lecture ${ }^{\mathrm{I}}$ upon Lord Lugard himself is at once 1 a task of great honour and of great difficulty. I need not explain to this audience why it is an honour: we know that we are here to recall the life and work of a great man, who was a creator of our Institute and for nearly nineteen years (1926-45) its Chairman. But the difficulty does need some explanation. I must attempt at least a preliminary evaluation of a life that was immense in the period of time covered and in the range, both in space and in character, of its activities. Yet I cannot assume that you have a full knowledge of that life since its story has yet to be told. Some here knew him in his later years; there are, indeed, some still alive who worked with him in the vigorous days of his prime. There is also his own vivid account of four of his most adventurous early years, ${ }^{2}$ and there is the impressive documentation of his governorships. But there are large areas in his youth and even in his manhood which are still quite unknown. And when these have been explored the parts have still to be put together to form a biographical whole. Here is my difficulty: I cannot, in the time we have this evening, attempt both to tell the story, even in outline, and to comment. Yet how can the story and the comment be divorced? I must attempt a compromise. I must offer you something not much more than a chronology of his life, and tell you a little-and how little it must be-of some of his earlier, less known achievements; and then, assuming your knowledge of his later life, offer, in all humility, my first provisional evaluation. I emphasize provisional because my biography is only half drafted and there is much, especially between his leaving Nigeria in 1906 and the latest part of his life when I knew him, that is still, for me, a subject for research.

First, one word of personal explanation. As Lugard's official biographer I feel like a monopolist entrusted with a great treasure-and a treasure of immense volume, since Lugard was a man who kept every document which came into his hands and a copy of each that went out from them. The trust came to me because of accidental rather than inherent merits: the chance that my studies had covered much of the sphere of his work; that my travels had taken me in his footsteps to almost every scene of his African adventures and administration and, most valued chance of all, that in the last sixteen years of his life I was often able, in a minor capacity, to work with him and to enjoy his friendship and, I dare to say, his affection.

This will naturally raise the question whether biography is the proper task of a friend. I can only reply that I recognize that warmth of sympathy and understanding must not be allowed to rise to the heat of partisanship. Nor, on the other hand, in

I The Lugard Lecture was founded by the International African Institute in memory of its first Chairman. The lecture is given annually on the occasion of the meeting of the Institute's Executive Council. This paper, the first of the Lugard Lectures, was read by Miss Perham at the Indisch Instituut, Amsterdam, on 3 April 1950, on the occasion of the 24th Meeting of the Executive Council, and was repeated at a special joint meeting of the International African Institute, the Royal African Society and the Royal Empire Society in London on 20 April 1950.

2 The Rise of our East African Empire, 2 vols. London: Blackwood \& Sons, 1893. 
the endeavour to achieve the temperature of history, must the writer withdraw into a frigid detachment. There is truth in the paradox of the Chinese sage (Lao-tze) ' to make up one's mind to be impartial is in itself a kind of partiality'. I am sure of one thing and that is that reverence-which is quite different from respect or affection -is the wrong attitude for the biographer, for it muffles our power of judgement and makes us forget that the living have an even greater call upon its services than the dead. This is because the issues with which a great man deals are, in their fundamentals, still with us and we must learn to deal with them by the recognition of his mistakes as well as of his successes. There may be a period after a man's death for certain silences, but not for false judgements which it may be difficult later to withdraw from currency. Thus it may be the hard duty of the historian who writes so soon to disappoint or even to offend. Fortunately, I can in all honesty feel that with this subject my duty will not be very hard.

Let us first review the immense stretch of Lugard's life and see how we can best divide it into periods. He was born in 1858 and he died in 1945 , in his eighty-eighth year. The years fall, I think, naturally into five periods with the following titles :

1858-78 The Youth
1878-88 The Young Soldier
1888-1900 The African Adventurer
1900-18 The Governor
1918-45 The Elder Statesman.

I propose, in this selective compromise that is forced upon me, to characterize very briefly the first, the second and the last periods and to give my main attention to the African adventurer and to his first governorship. Those I believe were, I will not say his greatest years, for the stages are not easily comparable, but the years of fierce energy, of marching, enduring, inventing, and building with his hands and his mind.

First, a few words on the twenty years of his youth, for little or nothing seems to be generally known of this. He was born in India, in Madras, the son of a chaplain in the East India Company, himself the son and the brother of distinguished soldiers. His mother was Mary Howard, descended from Yorkshire landed gentry, a young lady strong enough in her religion and strength of character to force her way out alone at that early date to Southern India as a missionary. Already weakened by hard work in the steamy climate of Madras, she bore her husband five children in five years and cared for his step-children-she was a third wife-until in 1863 she was forced to return to England with six young children in a sailing-ship; it was a terrible voyage in which five-year-old Frederick met his first dangers and first showed his mettle.

His father was a man of great charm, gentle and deeply religious. I believe, however, that the steel and fire in Lugard's character came, by nature and by nurture, from his mother. He was brought up by her in a large family under the strictest discipline, based upon evangelical piety but sweetened and stimulated by her love and high spirit. It was a childhood of family prayers, of bible-reading, of religious conversation, of mutual service and courtesy, of family lessons and home-made clothes, of duty and hard work in a setting of poverty. Lugard's great joy was the Bible his mother 
gave him: he spent hours-at six years old-poring over it and learning texts by heart until he would lie sleepless in bed crying over his sins.

His mother died after her husband's return to England in $186 \mathrm{~g}$, when Lugard was seven years old. The loss of her love and control was overwhelming both to the father and the children. Money worries were ceaseless and young Lugard was at times subject to moods of reserve and gloom. He was first sent to a Moravian school near Manchester where he was subjected to thrashings and a stupid discipline by German masters. After this he was sent to Rossall School, where he encountered high winds and a hard life, some bullying and the anguish of being short of pocket-money, but got a good classical education. From Rossall he went to Sandhurst, passing sixth of a thousand candidates. He gained this privilege after an education which, you will observe, broke most of the rules of modern educational psychology. The pious Victorian childhood, the youth in which the consciousness of being born a gentleman gave him the ambition for a life of distinguished service, while his poverty forced him into ceaseless hard work in order to make good his claim to it-here is a combination of influences which can never be repeated.

Part II, the young soldier, must be passed over very quickly. It was a period in which he was carried hither and thither about the world with the ebb and flow of Britain's imperial policy. The first forward wave swept him out of Sandhurst, after only eight weeks, into his regiment and out to the North-west Frontier. The impetus of the wave was Disraeli's imperial policy which, leading to a Russian crisis, eventually landed young Lugard, half dead with fever, in Peshawar, and then in the Khyber and Kabul to take part in the Second Afghan War, one of the most inefficient and fruitless campaigns in which Britain has ever engaged.

This was followed by three years of peace-time soldiering in India-the only place where he could afford to be a soldier. It was the India of Rudyard Kipling, of Mrs. Hawksbee and the fishing fleet on one side, of Kim and Mowgli on the other. There is no evidence that Lugard appreciated either of the contrasting extremes. His was the India of hard work on the drill ground and rifle range, of swotting up for examinations, in transport and Hindustani in order to get proficiency pay, of experiencing the delicious taste of danger in reckless polo, pig-sticking, and tiger-shooting. From here he was whirled off by the death of General Gordon to fight the 'Fuzzies' behind Suakin, this time on an imperial ebb-tide under Gladstone, a thirsty, bloody, and abortive little campaign, fought on account of national pique rather than for any rational purpose. From the deserts of Suakin he went as transport officer to the wet, feverish forests and tiver valleys of Burma on the third Burmese War, in which Britain conquered the kingdom of Thibaw.

It was at this point that an event occurred which completely changed Lugard's life. He had a great capacity for affection, which lay hungry and almost unsatisfied since his mother's death. After assuming in India a kind of cynical schoolboy aloofness from women, the first stroke fell upon his heart with crushing power. Then there came a moment when, wearied with the Burma campaign and sick with the peculiarly melancholy fever of that humid country, he came to England and found, in one moment, that he had made a complete and terrible mistake. With his ardent nature the double effect of fever and misery nearly destroyed his reason. He wanted to turn wholly away from all that belonged to his old life and seek forgetfulness in new 
and dangerous courses. Danger was not easy to find in London, but he joined the Fire Service and went out night after night in reckless encounter with the great London fires.

This was not anodyne enough, and he was soon travelling, a nameless and almost penniless adventurer, sleeping on a filthy deck among Arab coolies and hanging round the cook's galley for whatever greasy remains might be left over. Thus he went down the Red Sea, being carried to Africa, somewhere, anywhere. He has told some of this story in the first chapters of his book. ${ }^{I}$ He had read much of Livingstone who, after all, had died only some fifteen years before, and he hoped vaguely to employ, and if necessary end, his life in some useful anti-slavery effort.

This was how the promising and ambitious young officer, well on the way to a conventionally successful military career, was violently diverted from his course and flung into a new, raw, and to him, utterly unknown continent.

I must ask you to remember the condition of tropical Africa when, in April i 888, Lugard, after drifting vaguely down the East African coast, found himself being paddled by six natives, to the rhythm of a guttural chant, between the creeper-laced jungles on the banks of the Zambesi. The vast interior of tropical Africa was still largely blank on the maps; the sites of a few occupations had been marked on the coast or a little inland, and a few spidery lines traced the deeper penetration of a handful of brave explorers, Park, Livingstone, Speke, and the rest. The scramble for Africa had only just begun. 'When I left the Foreign Office in 1880', said Lord Salisbury, 'no one thought about Africa. When I returned in 1885 the nations of Europe were almost quarrelling with each other as to the various portions of it which they could obtain.' By 1888 , claims were being staked on the coasts, but it was not clear just how the lines would run inland, what regions were best worth seizing, and how claims on paper could be made good in the vast, wild, unhealthy interior. The race was still to the swift and the strong. But the British Government, then isolated in Europe, was by no means ready to send official expeditions to take the physical, financial, and diplomatic risks of annexation. Individuals-missionaries, traders, and patriots who were neither-were outrunning governments, forming companies, undertaking tasks beyond their resources, and looking for men of strength, courage, practical ability, and adventurous will, to be the spearheads to penetrate and annex the new continent.

We find, therefore, that in the twelve years from I 888 to I 900 Lugard was engaged in five adventures in Africa and that the first four of these were in the employment of companies, two of them chartered and two trading companies. The regions were Nyasaland, Uganda, Nigeria, and the Kalahari (or Bechuanaland). The fifth and last adventure, again in Nigeria, was the only one in which he served the Government.

It is clearly impossible for me to sketch the crowded events of these twelve years, as full of drama and excitement, of daring escapes, forced marches, wild men and wild animals, of thirst and fever, of poisoned arrows and hand-to-hand encounters, as any imaginary adventure story written to thrill the blood of schoolboys. I can do no more than glance at some of the less-known aspects and incidents of this period and endeavour to measure Lugard's work in this breathless process of annexation.

The first two adventures, on Lake Nyasa and in Uganda, are fully described in the 
book which was published in 1893 , though there is much on the personal and political side that can be added. We know how he offered his professional services to the Scottish missionaries who were threatened by the Arab slavers with the fate that was befalling the wretched tribes around them. This area was then still a political noman's-land. But in spite of a reluctant British consul, who knew he had an even more reluctant government behind him in Whitehall, Lugard led a little band against the slavers' stronghold. He fell as he reached the top of the stockade, shot point-blank by a bullet which went into his right elbow, through his chest, and blew the letters in his breast pocket into his left arm, leaving him to walk for two hours, with six powder-blackened suppurating wounds, to die, as all expected, in his camp. His resolute intervention may not have been decisive, but he certainly gained time for the hard-pressed missionaries and the African Lakes Company which supported them.

There were two other important results. He did not die and he forgot that he wanted to die: Africa had gripped him. The other result was that when Salisbury still hesitated to annex Nyasaland, or to intervene to protect the missions, Lugard remembered, junior army-officer though he was, that even Salisbury had a master. Thus he began, by writing and lecturing, his long appeal to the British public to interest itself in Africa, that has left on the shelves some fifteen large volumes of his writings and speeches. $\mathrm{He}$ was neither a brilliant speaker nor a brilliant writer but he had something to say and he said it clearly and fully-often too fully-and did much over the years to inform and influence his countrymen. Indeed, almost from the moment when he stepped upon African soil, though apparently down and out, he ceased to be a mere $\operatorname{cog}$ in the vast military machine and began to exercise his will upon Africa and upon international events.

Uganda was a much bigger affair than Nyasaland. The Imperial British East Africa Company, though it was hardly consolidated on the coast, was forced to reach out hundreds of miles into the interior, to Lake Victoria and the sources of the Nile, in order to keep the peace in that astonishing little kingdom of Buganda. Its people had just eagerly absorbed what they regarded as three new religions, Anglicanism, Roman Catholicism, and Islam, and were indulging in a three-sided civil war as a result. The Company had also to ward off German annexation personified by the intruding Karl Peters. Lugard took service with the Company and walked his caravan of Swahili porters and fifty so-called soldiers through that 600 miles of forest, bush, and open downland that was to be called Kenya, and on another hundred miles into the king's dangerous capital.

He marched in at a critical moment in British imperial policy. The old Liberals and Radicals, Gladstone, Harcourt, and Morley, were making a last stand in defence of their Little England policy, while Rosebery, young Edward Grey, and the new Liberals were drawing apart from them. On the other side, Salisbury and Chamberlain were beginning to face the responsibilities of empire. There are thus two sides of the Uganda story : one in and around Kampala, the other in Westminster. The Uganda side has been told in all its full and exciting detail by Lugard himself. We know how he obtained his treaty from the vacillating King Mwanga; how he kept the peace between the three restless, shifting parties; how he made his great march west and north to fetch the stranded Sudanese soldiery of Emin Pasha; how war broke out to be settled by one burst from a faulty Maxim gun; how he imposed his final 
settlement. By this time he knew that the Company was withdrawing, that the missions could only support it for a time, and that all he was doing might go up in flames at any moment, and himself with it.

There was the other, much less well known side of this story, as each event in Uganda had its repercussion, five or six months later, in Britain. Here the Company and the missionaries pleaded for the annexation of Uganda; the Liberals, led by Harcourt and Labouchère, denounced this as 'jingoism with a vengeance', while between them, first Salisbury and then Gladstone hesitated to take the plunge into annexation. Lugard's name was batted to and fro like a shuttlecock in a series of parliamentary debates, a symbol of policy, his future, and indeed his life, at stake.

The issue was not decided when he arrived home in 1892, after three strenuous years, and flung himself immediately into the British end of the conflict. He made a whirlwind tour round Britain and to Livingstone's Scotland. As a soldier he was not allowed to talk politics, but he could give scientific geographical lectures and he did! Great cities gave him civic receptions; he wrote for the Press; he worked in the lobbies; as a social lion he met royalty, and dined and spent week-ends in all the great and lesser political houses. He wrote his book and shocked the brilliant Flora Shaw, colonial editor of The Times, by calling upon her and telling her just how to review it. In the end Gladstone was warned by his election agent that if he evacuated Uganda he would evacuate Downing Street. So the battle was won in London as well as in Uganda and in both places Lugard helped to win it. The victory was, indeed, a narrow one: there were strong forces against expansion, and the general attitude is expressed by Punch's two cartoons on the subject. One shows Uganda as a white elephant with the Company begging John Bull to take over the animal as he can do nothing with it. The other, at the date of annexation, shows John Bull opening his front door to find a black baby marked Uganda deposited on his door-step. Throwing up his hands in resigned despair, he says, "What, another! I suppose I must take it in.'

Lugard's next adventure was on the other side of Africa. He longed to go back to Uganda but the Foreign Office, which then had control of East Africa, resented his masterful behaviour and feared his unpopularity in France. But a keen and resolute eye had marked his abilities. Sir George Goldie, that ruthlessly efficient and farseeing creator of the Royal Niger Company, had marked him down as the ideal man for his purposes. His Company, though infinitely more prosperous than its opposite number in the east, was in grave political difficulties. It was in almost open conflict with the French over the disputed western frontier of its domain. Here, too, the Government was not yet ready to intervene. Thus Lugard, who at this time fell completely under the spell of this remarkable man, found himself in 1894 engaged in what the French called the 'Steeplechase for Nikki'.

Nikki was the reputed capital of the unexplored pagan kingdom of Borgu which lay in the bend of the Niger. Whichever national agent could reach this place first and make a treaty with its king would, it was believed, win the whole disputed kingdom. The rival expeditions started. Lugard had a terrible journey. He led men whose language he could not speak, in country he did not know, with two other white men only just arrived in the country, and with transport of donkeys which crumpled, as he said, like brown paper, in the ceaseless rain. On one occasion, when the whole 
expedition was in danger, he went alone by night to parley with an unknown pagan king, a meeting at which they became friends for life. By the sheer fixity of his will he drove himself and his half-mutinous men through unexplored swampy bush, past hostile chiefs and kings, reached Nikki sixteen days before his French rival and got his treaty. On the way back his force was ambushed: he was struck in the head by a poisoned arrow, his servant dragged him along the ground with it before he could get it out, with a bit of his skull adhering to it, and he was then fed with every filthy nauseating antidote his men had with them.

Adventure No. 4 was of a very different character. Lugard was restless and unemployed after his Borgu expedition. Chamberlain, though now his firm friend and admirer, was unable to find a use for such a fierce and famous agent who was by now, not unnaturally, very unpopular in France. Still almost penniless, he agreed for a very high salary to conduct an extremely difficult expedition through the Kalahari desert, to gain a treaty and to prospect for minerals for another Company, the West Charterland. One of the main inducements was that he could take with him as second his younger brother Edward, to whom he was deeply attached. There is no time to tell this story with its almost miraculous triumphs over transport problems at a time when the great rinderpest epidemic had almost wiped out the oxen which should have drawn the wagons. He found neither gold nor diamonds. But he met and instantly made friends with the great chief, Khama, and he learned much, physically and politically, of southern Africa.

From his camp near that strange Lake Ngami he was recalled by a runner bringing him a telegram from Chamberlain which summoned him post-haste to England for his fifth adventure. A grave situation had arisen between France and Britain: the storm-centre was again in the Niger bend. But this time the Imperial Government, with a determined Chamberlain stiffening a less determined Salisbury, had at last decided to intervene officially. Lugard was commissioned to create the West African Frontier Force with the utmost speed and take it out to guard the line west of the Niger from further French penetration.

This is at once a most important and a fascinating chapter in Lugard's life. His relations with Chamberlain brought out the ever-latent conflict between the soldier and the politician who uses him; there were also his relations with the embittered Goldie who faced the loss of his Company's charter; there was the part played by Flora Shaw and Mary Kingsley-all these combined in deeply interesting human action behind the scenes. But the play itself was grave enough. Lugard's diary throws important light upon Chamberlain's rock-like determination on this question, even at the risk of war. And while Lugard's columns penetrated those of the French, with the hourly fear that the guns would go off by themselves, war was a very real possibility. But Lugard held the line and the countries came to terms. The storm-clouds passed eastwards from the Niger to the Nile where, it will be remembered, they hung for a time over the little post of Fashoda. These are incidents which France and Britain can afford to forget, or rather to remember, because of the courage and chivalry shown by the men who carried their flags through the African bush to the two great rivers, and because the story leads on to the happy ending of the entente.

What was the significance of these five adventures in the twelve years during which 
tropical Africa was partitioned by Europe? It is tempting to a biographer to magnify the part played by his subject. But the movement was too multiple in places and persons for any one man to play a decisive part. Yet Lugard's contribution was large, and this was due to no accident, except for that first chance which diverted him from one continent to another at a moment of opportunity. It was due to a rare combination of gifts--the strength of his tense, small body, undefeated by fever, wounds, thirst, dangers, and the almost impossible calls upon its endurance through long days of marching in sun or rain. There was also his great experience as a transport officer, his skill in handling animals and gear and, above all, men. Men, too, of unknown race and tongue, who needed the right mixture of discipline, leadership, and the human touch to carry them through the dangers and difficulties of the march. Lugard was no doctrinaire or sentimental negrophile, but he carried the highest standards of his country and civilization into lands far beyond their influence, and once there he did not abandon them. He was always just and humane; he judged each man on his merits and was as quick to like and to trust an African as a white man. He did not stoop, as Karl Peters and, to a lesser extent, Stanley had stooped, to harsh measures which would have thrown a shadow on his name and that of his country. To this we must add his skill, dignity, and patience in negotiating treaties with African chiefs and his determination that the transactions should be as clear and honest as he could make them. And if he had all the qualities needed to meet the remorseless test of the Africa of his day - a test of mind and spirit no less than of body - he had also those other qualities which enabled him to fight his African battles in the place where the ultimate decision lay-in Britain, in the Press, on the platform, in the provinces, in Whitehall and Westminster.

All this is to say how he achieved what he did, not why. We come here to the most presumptuous task of the historian and the biographer-the attempt to distinguish motives. This can be done as yet only in a very tentative way. I believe, then, that Lugard had natural human ambition to the full. He also had a most unusually strong and independent will. He could hardly bring himself to work under another man. In Africa he found, like that great Frenchman Marshal Lyautey, whom in many ways he resembled, the perfect field for the untrammelled exercise of these qualities. But this unusual measure of human energy and initiative might have been turned to merely self-regarding ends had it not been for the bent given to his character by his early Christian training and by all the other influences-including his friendship with men like Sir John Kirk-which confirmed those early attitudes resulting from the child's training in self-discipline and the young soldier's in loyalty and duty.

Thus he set himself to serve his country and to serve Africa while at the same time he certainly thought it no sin to covet personal honour. In action the three motives were fused into one. I am sure he never admitted any conflict between them. To understand how this could be, it is necessary to trek and camp and fight with Lugard, as his diaries allow us to do day by day, and to see Africa as it was in the eighties and nineties. It was no black Arcadia; even if it ever had been that, it was now being ravaged by the Arab slave-trade. The raids which supplied it were spreading wars, famines, and demoralization over wide areas. Lugard saw slavery face to face as Livingstone had done. He met caravans of slaves on the march; he found ruined villages, and himself nursed in his tent slave-children he had freed. A man with an 
intense belief in order, he loathed slavery, not with passion but with a cold, precise determination to end it. In characteristic manner, as well as repressing it practically, he made a deep study of it and became one of the leading theoretical experts on the subject. To him it seemed clear that nothing better could come to the divided, disordered tribes than British rule. The alternative, he saw, was no longer what some men would - in his view mistakenly - call 'freedom'. It was annexation by some other European power. And Lugard had, I must confess, an absolute faith in his own nation. And so, though a deeply humane man, always anxious to avoid the use of force, he was prepared to use it in order to extend what he regarded as the priceless benefit of civilized government. Was he wrong? There were a few then who said that he was. There are more, including Africans who have not always studied their own history, who would say the same to-day. How can we judge such a question? I think that, until African history has moved on into a much clearer perspective, no judgement will be valid. In the meantime this country has tried to show in action, ever since these annexations, that they were right for Africa as well as for Britain.

Lugard, then, had helped to annex large regions of Africa in the faith that Britain could give them order and civilization. Now Fate seemed to turn on him and say, 'Very well-make good your boast. You have annexed. Prove that you can govern!' This brings us to the fourth period of Lugard's life-that of the Governor. We have reached that part which is best known, described as it is in his numerous memoranda and reports, crystallized in the traditions and institutions of Britain's largest colony, and later reduced to a philosophy in The Dual Mandate. ${ }^{\mathrm{I}}$

We all know that as High Commissioner for Northern Nigeria, which he took over from Goldie's Company in 1900 , he was the creator of 'indirect rule'-that special application of a principle or device that was as old as empire. I believe that this first governorship, 1900-6, was his great creative period as an administrator. He might, indeed, have been especially trained by a thoughtful Providence for the task that now came to him. He was soldier, explorer, an expert on transport, on slavery, on prospecting, on dealing with native potentates, not to speak of Colonial Office officials, politicians, and public. He was asked to govern a vast new region, two-thirds of which had still to be conquered, a task which he achieved in his lightning, almost bloodless and only half-authorized Kano campaign. He had at first only half-a-dozen or so political officers, a handful of local levies and what must seem to us to-day a derisory grant-in-aid from a then economical Parliament paid out by a grudging Treasury. He filled the gap partly by the inspired opportunism of his political settlement, partly by driving himself and his staff-but above all himself-almost to death with overwork. And-need we add-as I have learned from a study of the archives, by fighting an almost ceaseless war with the Colonial Office which wanted this dynamic man to run Nigeria on a 'care and maintenance' basis.

I need do no more than remind you of the main feature of his famous system. It is sometimes said that he had no choice and was wholly governed by his shortage of staff and of money. But I hope to show in my book that within the limits set by these there was a wide choice of methods and that his settlement was based upon a considered respect for the people under his rule and for their institutions. He based it upon a claim to absolute sovereignty. Having frankly assumed full power by right

I The Dual Mandate in British Tropical Africa. London: Blackwood \& Sons, 1922; 2nd edition 1929. 
of conquest he then made a generous retrocession of power to the Emirs, forging an unbroken chain of responsibility from British Resident to village head. Rejecting the idea of two parallel systems, in law and in administration, he dovetailed native into imperial power and, after as close a study of native custom as was then possible, he devised a reformed native judiciary and system of taxation; finally came the elaborate rationalization of his instructions in his political memoranda. His policy was the rejection of two extremes-the almost complete native self-rule of the Indian States on the one hand, and on the other the more direct rule which he would have been able gradually to impose as his administrative grasp increased. The merits of the system are well known. It was brilliantly successful in practice. It was also remarkably economical. And it was a perfect shock-absorber for the moment of European impact upon a highly organized African society. It thus became a model, deliberately copied by some other colonies and influencing nearly all of them far beyond Africa.

A model! The very word suggests something static. A good system of administration is indeed liable to a peculiar penalty. Created by a man of high ability, it may become sanctified by its very success. Then it may be reverently or lethargically prolonged or exaggerated by other men until its active principle weakens and it hardens into the preservation of the outward forms. Has this been true of Lugard's 'indirect rule'? Here again it may be too soon to say. But I believe there was from the first an inner contradiction in the use of native kingship by British rulers, which at least one man, Sir Charles Orr, foresaw at the time. The contradiction could not then appear fully, and perhaps it was at first inevitable; it could become harmful if the conditions of the original settlement, through the lack of an active policy of reform and adaptation, should become crystallized. I do not think Lugard fully saw the danger, and when later he came back to Africa after an interlude (indeed, an exile from Africa in Hong Kong), he was overwhelmed by the vast jig-saw puzzle of amalgamating the two Nigerias, and extending indirect rule to the south, and by the distractions of the First World War. He was handicapped also, perhaps, by his own reluctance to delegate, and by an over-conscientiousness with regard to his office work which tied him too much to his desk. Thus it may be that he was not able to bring to the task of adjustment the administrative genius he put into creation.

Yet though I ventured to raise these questions, they are only questions. We cannot deal here with his Governor-Generalship of all Nigeria and, indeed, I have not yet fully studied it myself. Whatever answers it may suggest to our questions; Lugard will remain a great governor, certainly the greatest Britain ever sent to Africa and the peer of the best that India knew.

We come to the last period. I have little time and perhaps little need to speak of it: it is the period when many of you knew him either in person or by repute.

We cannot speak of Lugard's retirement; he never retired! From the moment he left Nigeria he continued with his long hours of work, sitting night after night until the small hours at his desk in his Surrey home among the pines and beeches of Leith Hill. What was he doing? What was he not doing? Writing-books, articles, reviews, prefaces, memoranda, letters to The Times, above all writing and then rewriting The Dual Mandate. Public affairs-sitting on select and standing committees, attending conferences, directing learned societies, encouraging African research, speaking in 
the House of Lords. International tasks-the Mandates Commission, the Slavery Commission, the Forced Labour Committee. For the rest, entertaining governors, cabinet ministers, and distinguished foreigners and conducting a vast correspondence. He helped anyone who asked help of a kind that he could give, not perfunctorily, but with the care and entire concentration which he gave to everything he did. The fierceness of action and ambition had gone, but his energy remained. His nature had been sweetened by a late but inexpressibly happy marriage with the brilliant colonial expert, Flora Shaw. It was later softened by the abiding sadness of her death in 1929. He became more and more unselfish and gentle, anxious only to serve and quite unreasonably modest. It was the result, perhaps; both of his courtesy and of his physical strength that he never to the very last claimed any of the privileges of age. The British members of this Institute will remember how he presided over a long meeting of its Bureau a few days before his death, as zealous to the last for its reputation and good conduct as he had been in the days of its creation.

As we review this life I think we must be struck by the range of Lugard's gifts. These allowed him to adapt himself to the rapidly changing conditions of the field in which he had chosen to act. Thus he was soldier, explorer, administrator, and, in his later life, the man of the pen, the student and the philosopher, the chairman of scientific societies, presiding over research and a leading figure in all international colonial affairs. It is the last two facets of Lugard's versatility which are of greatest interest to us here. With them, as with his other manifestations, I think he did not attain new qualities and ideas but rather developed old ones. The germ of his scientific interest had always been there. As a pioneer traveller, still more as a Governor, he had recognized the need for knowledge deeper than he could then acquire, as the only basis for effective government and good relations with the people. He was humble enough, as not all Governors have been, to recognize the limitations of his own administrative intuition and to value what only the student and the scholar can give. Moreover, as the opportunity for more active service left him, his desire to work for Africa led him to seek out all ways in which he could still contribute. So, to the great advantage of anthropological research, he brought the dignity of his status and the wealth of his African experience to this Institute. He did not himself become an anthropologist : he appreciated the need for research in this field rather than its content. I would not like to state that he even read all the anthropological studies which were planned and carried out under his chairmanship.

The other apparent change which is very relevant to our Institute was the development of one who had appeared to be so militantly national into a most effective internationalist. But here, too, there was neither change nor contradiction. The Africa he knew in all its immensity and poverty could not, he realized, be civilized by one nation; as a good European who had adopted Africa, he believed that the colonial powers should keep in step and move towards common and defined ends. And perhaps the best internationalists are those whose own deep patriotism gives them the confidence to co-operate and a respect and understanding for the national feelings of others. But his desire for co-operation and research was based upon something even wider than the interests and duties of colonial governments. He realized the need to bring Africa into the wider world not only of science but of ideas and action for human progress. Hence the time and energy which he gave in later life to 
the great experiment at Geneva, and above all to the Mandates Commission, the records of which will remain as evidence of his good sense and sincerity.

We have looked back over Lugard's life and seen that he was for many reasons a memorable man and that there are some special reasons why we in this room should remember him. But as we look forward we see that his work has relevance for the future also. This is partly because his work and ideas have so deeply influenced British administration, not only in Nigeria but in other parts of Africa, that they have become part of the Africa we study, as worthy of our attention as the older phenomena and, indeed, inextricable from them. The other reason is that, as the political control of the western world over Africa retreats or changes its nature, the cultural relations between the two sides will become ever more important. The Institute has, therefore, a great part to play in interpreting Africa not only to the rest of the world but to her own peoples. There are qualities in our first Chairman-his respect for other nations and other races, the confidence in our civilization which he carried unshaken through two world wars, above all, perhaps, his integrity of mind-which should inspire us in the task which he has handed on to us.

\section{Résumé}

\section{LORD LUGARD: UNE APPRÉCIATTION PRÉLIMINAIRE}

CETTE communication constitue le texte de la première des conférences instituées par l'Institut Africain International, pour honorer la mémoire de Lord Lugard, son premier président. La conférence fut faite par Mademoiselle Margery Perham le 3 Avril r950, à Amsterdam, lors de la réunion du conseil exécutif de l'Institut.

Mademoiselle Perham, qui doit achever prochainement la biographie officielle de Lord Lugard, traça les grandes lignes de sa vie, de 1858 à 1945 , et souligna la portée tres étendue de ses activités. Elle décrivit son enfance pieuse dans l'ère victorienne, ses aventures au cours des diverses guerres coloniales des années quatre-vingt et son affection dramatique et soudaine à un poste en Afrique, continent dont de nombreuses régions restaient encore à explorer. Entre I 888 et 1900, il entreprit des expéditions dangereuses et difficiles dans le coeur de l'Afrique, pour le compte de quatre compagnies différentes, dont les activités dépassaient l'action d'un gouvernement encore hésitant. Ses aventures furent plus émouvantes qu'un récit de pure fantaisie. Il prit part, également, dans les polémiques politiques qui furent soulevées au sujet de l'annexion des territoires africains et devint un ami de Joseph Chamberlain et de bien d'autres personnalités de l'époque. Finalement, en 1898, Chamberlain le chargea de l'organisation des forces armées de la frontière de l'Afrique occidentale et de contester à la France les frontières occidentales de la Nigérie.

Dans sa description de la période suivante de sa vie, pendant laquelle il fut Gouverneur de la Nigérie (1900-1918), Mademoiselle Perham traita brièvement du système d'Administration indirecte introduit par Lugard, du succès remporté par ce système à l'epoque, et des critiques formulées ultérieurement. Ensuite, Mademoiselle Perham décrivit l'œuvre immense accomplie par Lord Lugard pendant sa retraite sur des aspects politiques, internationaux et scientifiques des affaires coloniales, et le volume énorme de ses écrits sur ces sujets, y compris son livre bien connu, The Dual Mandate. La diversité de ses talents lui permit de contribuer largement, et de diverses façons, aux affaires africaines, au cours des trois périodes principales de sa vie. 